\title{
A WARNING FROM THE PAST
}

He was in plain clothes, his instinct was to

escape. Here was the risk; as he appeared

on the top of the wall shots might ring out.

He heaved himself up . . . his waistcoat hooked

on to something ... he freed it ...

he saw a sudden glow in the cupped hands of

a sentry lighting his cigarette... He dropped

into the garden and crept into some bushes.

To his horror he realised he had left his

food tablets, map and compass on the

wrong side of the wall, as a result of which

he later suffered considerably.

The moral is still the same:

Always Carry Your Escape Aids with You!

This prisoner who escaped in the Boer War became

British Prime Minister Winston Churchill.

(MI9 bulletin, WO 208/3268) 